Elsevier

BRE 10874

\title{
Localization and Function of Cat Carotid Body Nicotinic Receptors
}

\author{
B. DINGER, C. GONZALEZ*, K. YOSHIZAKI** and S. FIDONE \\ Department of Physiology, University of Utah School of Medicine, Salt Lake City, UT 84108 (U.S.A.)
}

(Accepted October 23rd, 1984)

Key words: acetylcholine - $\alpha$-bungarotoxin - autoradiography - carotid body - dopamine release — nicotinic receptors

\begin{abstract}
Acetylcholine and nicotinic agents excite cat carotid body chemoreceptors and modify their response to natural stimuli. The present experiments utilized $\left[{ }^{125} \mathrm{I}\right] \alpha$-bungarotoxin $\left(\left[{ }^{125} \mathrm{I}\right] \alpha\right.$-BGT) to localize within the chemosensory tissue the possible sites of action of exogenous and endogenous nicotinic cholinergic substances. In vitro equilibrium binding studies of intact carotid bodies determined a $K_{d}$ of $5.57 \mathrm{nM}$ and a $\mathrm{B}_{\max }$ of $9.21 \mathrm{pmol} / \mathrm{g}$ of tissue. Chronic section (12-15 days) of the carotid sinus nerve (CSN) did not change the amount of displaceable toxin binding. In contrast, the specific binding was reduced by $46 \%$ following removal of the superior cervical ganglion. Light microscope autoradiography of normal, CSN-denervated and sympathectomized carotid bodies revealed displaceable binding sites concentrated in lobules of type I and type II cells. Treatment of carotid bodies with $50 \mathrm{nM} \alpha$-BGT in vitro reduced by $50 \%$ the release of $\left[{ }^{3} \mathrm{H}\right]$ dopamine (synthesized from $\left[{ }^{3} \mathrm{H}\right]$ tyrosine) caused by hypoxia or nicotine, and also significantly reduced the stimulusevoked discharges recorded from the CSN. The data suggest (1) an absence of $\alpha$-BGT binding sites on the afferent terminals of the CSN and (2) that nicotinic receptors located within parenchymal cell lobules may modulate the release of catecholamines from these cells.
\end{abstract}

\section{INTRODUCTION}

The carotid body is an arterial chemosensory organ whose parenchyma consists of two distinct cell types in close association with a dense capillary network. Type I (glomus) cells possess abundant dense and clear cored synaptic vesicles, mitochondria and a highly conspicuous rough endoplasmic reticulum. Specialized terminals formed by afferent fibers from the carotid sinus nerve (CSN) synaptically appose the type I cells while slender cytoplasmic processes of type II cells, whose cytology resembles Schwann cells, envelop the afferent terminal-glomus cell complex.

In 1936, Heymans et al. ${ }^{34}$ were the first to observe that small intracarotid doses of acetylcholine (ACh) stimulated respiration in a manner similar to natural stimulation of the carotid body. In the ensuing decades, numerous studies investigated the role of $\mathrm{ACh}$ in chemosensation and demonstrated that small quantities of cholinergic agonists and antagonists profoundly altered chemoreceptor discharge ${ }^{20}$. Neurochemical investigations indicated that the metabolic machinery necessary for ACh synthesis, storage and inactivation appear to be associated with type I cells in the carotid body2,3.23,24,31,35,36 and that afferent fibers of the CSN are nearly devoid of cholinergic activity 23,28 . In addition, it has been demonstrated that an ACh-like substance is released upon stimulation of the organ in vitro ${ }^{17,18}$.

While these data support the notion that ACh may play a role in carotid body chemoreception, the precise actions of this substance in the sensory process has been elusive, particularly with respect to its putative action as a mediator or transmitter of chemosensory information from the type I cells to the afferent fibers of the CSN. Disagreement about the function of ACh stems from the observations that (1) anticho-

\footnotetext{
* Present address: Departamento de Fisiologia y Bioquimica, Facultad de Medicina, Valladolid, Spain.

** Present address: Akita University School of Medicine, 1-1-1, Hondo, Akita 010, Japan.

Correspondence: S. J. Fidone, Department of Physiology, University of Utah School of Medicine, 410 Chipeta Way, Research Park, Salt Lake City, Utah 84108, U.S.A.
} 
linergic agents completely block the effects of exogenously applied $\mathrm{ACh}$, but not the response to natural stimuli ${ }^{43.45 .51}$ (but see also ref. 49); and (2) exogenous $\mathrm{ACh}$ enhances chemosensory discharge in the cat ${ }^{17.22}$ while similar doses in the rabbit produce inhibition of discharge ${ }^{13.46}$.

A fundamental problem regarding the actions of $\mathrm{ACh}$ in the carotid body has been the uncertainty about the locus of its specific effects on type I cells vs afferent nerve terminals. Previous attempts to demonstrate pharmacologically the chemosensory involvement of ACh have not been convincing, since neither the sites of action of the applied drugs, nor the nicotinic vs muscarinic nature of the cholinergic receptors were clearly differentiated. In the present study, we have set out to characterize and localize nicotinic receptors in the cat carotid body using the labeled nicotinic antagonist, [125I] $\alpha$-bungarotoxin ([125I $] \alpha$-BGT). We describe here the equilibrium kinetics of toxin binding in normal cat carotid body, and the use of autoradiographic and biochemical techniques to assay toxin binding following chronic section of the CSN or removal of the superior cervical ganglion. In addition, the results of physiological and pharmacological experiments indicate a functional role for nicotinic receptors in modulating the release of catecholamines from type I cells. A preliminary report of these findings has already been published ${ }^{12}$.

\section{MATERIALS AND METHODS}

Three groups of adult domestic cats of both sexes weighing $2.5-4.0 \mathrm{~kg}$ were used in this study. In one group, the CSNs were bilaterally resected 12-15 days prior to the binding assay. In a second group, the superior cervical ganglia, which provide the sympathetic innervation to the carotid body vasculature, were surgically removed also at 12-15 days prior to the binding assay. All surgical resection procedures were performed aseptically under pentobarbital anesthesia. A third group of cats consisted of normal unoperated animals.

\section{Binding assay}

Carotid bodies were removed from anesthetized animals and cleaned of surrounding connective tissue in a lucite chamber filled with $\mathrm{O}_{2}$-equilibrated, mod- ified Tyrode's solution (in $\mathrm{mM}: \mathrm{NaCl} 112, \mathrm{KCl} 4.7$, $\mathrm{CaCl}_{2} 2.2, \mathrm{MgCl}_{2} 1.1$, Na glutamate 42 . HEPES 5 $\mathrm{pH} 7.43$ at $37^{\circ} \mathrm{C}$ ). Wet weight was determined on at Cahn electrobalance fitted with a humidified chamber to prevent drying of the tissues. Tissue samples were placed in vials containing $1.5 \mathrm{ml}$ of $\mathrm{O}_{2}$-Tyrode's solution plus $1 \%$ bovine serum albumin, and were preincubated in a waterbath shaker at $37^{\circ} \mathrm{C}$ in the presence or absence of either D-tubocurarine (D-TC; $10^{-6}$ to. $10^{-3} \mathrm{M}$; Sigma), or ACh $\left(10^{-6}\right.$ to $10^{-3} \mathrm{M}$; Sigma) plus eserine $\left(10^{-5} \mathrm{M}\right.$; Sigma). Following $20 \mathrm{~min}$ of preincubation, [ $\left.{ }^{125} \mathrm{I}\right] \alpha-\mathrm{BGT}$ (spec. act. $138 \mathrm{Ci} / \mathrm{m}$ mol, New England Nuclear) was added to the vials to reach final concentrations of from 1.0 to $45.0 \mathrm{nM}$. Incubation continued at $37^{\circ} \mathrm{C}$, after which the tissues were washed in $10 \mathrm{ml}$ of ice-cold Tyrode"s solution. For biochemical analyses, tissue samples were digested for $4 \mathrm{~h}$ at $60^{\circ} \mathrm{C}$ in a mixture of $200 \mu \mathrm{l} \mathrm{NCS}$ (Amersham) and $50 \mu \mathrm{l}$ water. Prior to counting in a liquid scintillation spectrometer, the digestion mixture was neutralized with $750 \mu \mathrm{l}$ of acetic acid $(1.3 \%)$, and $15 \mathrm{ml}$ of counting cocktail (PCSII, Amersham) were added to each vial. Specific binding was defined as the binding in the absence of either $D$ $\mathrm{TC}$ or $\mathrm{ACh}$, less the binding in the presence of these substances. The data are expressed as pmol radiolabeled-ligand bound/g of tissue ( \pm S.E.M.), and evaluated using Student's $t$-test

\section{Autoradiography}

[125I] $\alpha$-BGT tissue samples for autoradiography were removed from the wash media, immersed in a $0.1 \mathrm{M}$ phosphate-buffered fixative (pH 7.6) containing $1 \%$ glutaraldehyde, $1 \%$ paraformaldehyde and $0.01 \mathrm{M} \mathrm{CaCl}_{2}$, and then postfixed in buffered $2 \%$ osmic acid solution, dehydrated in ethanol, and embedded in Epon. Semithin sections were cut, mounted on glass slides and coated with Kodak NTB2 emulsion using a constant rate withdrawal apparatus (48 $\mathrm{mm} / \mathrm{min}$ ). Autoradiographs were exposed for 6-7 weeks, developed in Dektol, and stained with methylene blue.

\section{Release studies}

The effects of $\alpha$-BGT on the release of [ ${ }^{3} \mathrm{H}$ ] dopamine and CSN discharge were determined according to previously published methods ${ }^{21}$. Briefly summarized, the carotid body was incubated for $2-4 \mathrm{~h}$ in 
$40 \mu \mathrm{M}\left[{ }^{3} \mathrm{H}\right]$ tyrosine (spec. act. $20-40 \mathrm{Ci} / \mathrm{mmol}$ ), after which the organ was mounted in a tiny platinum wire basket suspended within a closed, temperature- and humidity-controlled chamber. The CSN was drawn up into an adjacent suction-type electrode. With the preparation in place, the carotid body was directly beneath an array of 22-gauge hypodermic needles which were connected through roller-type pumps (Technicon) to reservoirs containing unlabelled modified Tyrode solution. The solutions were preheated and gas-equilibrated in the reservoirs; final heating of the solutions to $37{ }^{\circ} \mathrm{C}$ was accomplished with a servo-controlled heating system. The temperature of the drop surrounding the carotid body was directly monitored through a second thermistor which was positioned to abut against the basket. The relative humidity in the chamber was maintained at $100 \%$ by a constant flow of gas, saturated with water vapor. This apparatus permitted a choice of 4 solutions, and the same gas was used to humidify the chamber and to equilibrate the chosen solution. Under control conditions the superfusate was equilibrated with $100 \% \mathrm{O}_{2}$, while stimulus solutions included $10^{-5} \mathrm{M}$ nicotine (equilibrated with $100 \% \mathrm{O}_{2}$ ), or superfusate equilibrated with $30 \% \mathrm{O}_{2}$. The drop rate from the needles was controlled by the speed of the pump, and the precise number of drops that fell from the carotid body was monitored by means of photocells mounted in the opening at the bottom of the chamber. The volumes of superfusate per collection period varied less than $5 \%$. The superfusion rate in all experiments was $0.4 \mathrm{ml} / \mathrm{min}$ and was established in preliminary experiments which assessed the viability of the preparation, judged on the basis of a stable chemoreceptor response over a $5 \mathrm{~h}$ superfusion period.

The action potentials from the CSN nerve were led through an AC-coupled preamplifier to an oscilloscope and a magnetic tape recorder. The amplified signals were also led through a window discriminator to (1) a frequency-to-voltage converter for final display of the spontaneous neural activity on a chart recorder and (2) a digital counter-printer which read the total number of nerve impulses recorded during the collection period.

The superfusates were collected in vials containing a carrier solution consisting of $0.3 \mathrm{M}$ acetic acid, $1 \mathrm{mM}$ ascorbic acid and $100 \mu \mathrm{M}$ unlabeled DA, at a final $\mathrm{pH}$ of 3.6. The solutions were processed with the alumina adsorption method for recovery of $\left[{ }^{3} \mathrm{H}\right]$ catecholamines, as described by Crout ${ }^{11}$. After elution of [ $\left.{ }^{3} \mathrm{H}\right] \mathrm{DA}$ with $0.3 \mathrm{M}$ acetic acid (recovery $65 \pm 5 \%$ ), further elution with $1 \mathrm{M} \mathrm{HCl}$ permitted the recovery of dihydroxyphenyl acetic acid (DOPAC) 25,55 , the principal DA catabolite in the carotid body 29 . The eluate of $0.3 \mathrm{M}$ acetic acid was further analyzed using high-voltage paper electrophoresis; the eluate containing [ $\left.{ }^{3} \mathrm{H}\right]$ DOPAC was directly counted in a liquid scintillation spectrometer. $\left[{ }^{3} \mathrm{H}\right] \mathrm{DA}$ release is expressed as the sum of $\left[{ }^{3} \mathrm{H}\right] \mathrm{DA}$ and $\left[{ }^{3} \mathrm{H}\right]$ DOPAC.

\section{RESULTS}

\section{Washout and time course}

Our initial experiments were designed to determine whether prolonged washing would dissociate significant amounts of bound [ $\left.{ }^{125} \mathrm{I}\right] \alpha$-BGT from intact (non-homogenized) samples of carotid body tissue. Carotid bodies were incubated for $3 \mathrm{~h}$ in $100 \mathrm{nM}$ [125I] $\alpha$-BGT in the absence of D-TC or ACh. The tissue was then transferred to wash vials containing $10 \mathrm{ml}$ of ice-cold Tyrode's solution. After $20 \mathrm{~h}$ of washing, the level of toxin binding was indistinguishable from that present after 1,2 or $6 \mathrm{~h}$ of washing. All subsequent experiments utilized a $1 \mathrm{~h}$ wash period. Under these conditions, non-specific binding never exceeded $35 \%$ of total binding in the normal carotid body.

The time course of [125I] $\alpha$-BGT binding is shown in

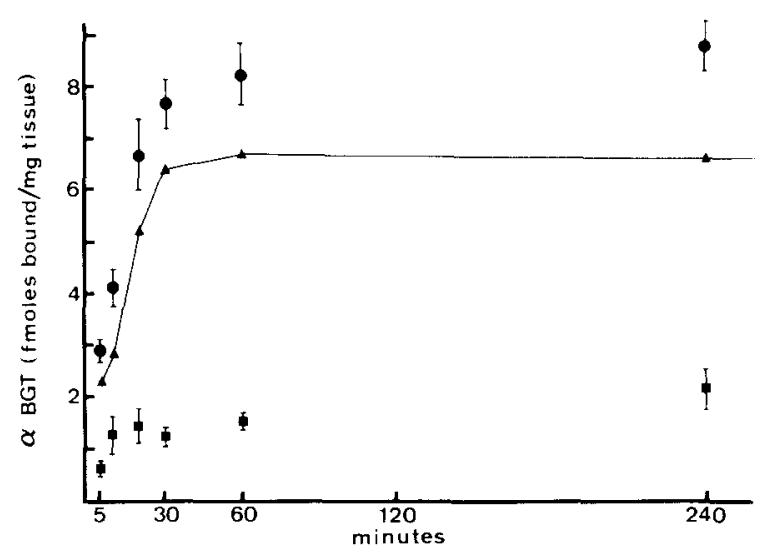

Fig. 1. Association time course of $\left[{ }^{125} \mathrm{I}\right] \alpha-\mathrm{BGT}$ with the carotid body. 1 , total binding; $\mathbf{E}$, non-specific binding in the presence of $10^{-3} \mathrm{M} \mathrm{ACh}+10^{-5} \mathrm{M}$ eserine; $\boldsymbol{\Lambda}$, specific binding. 

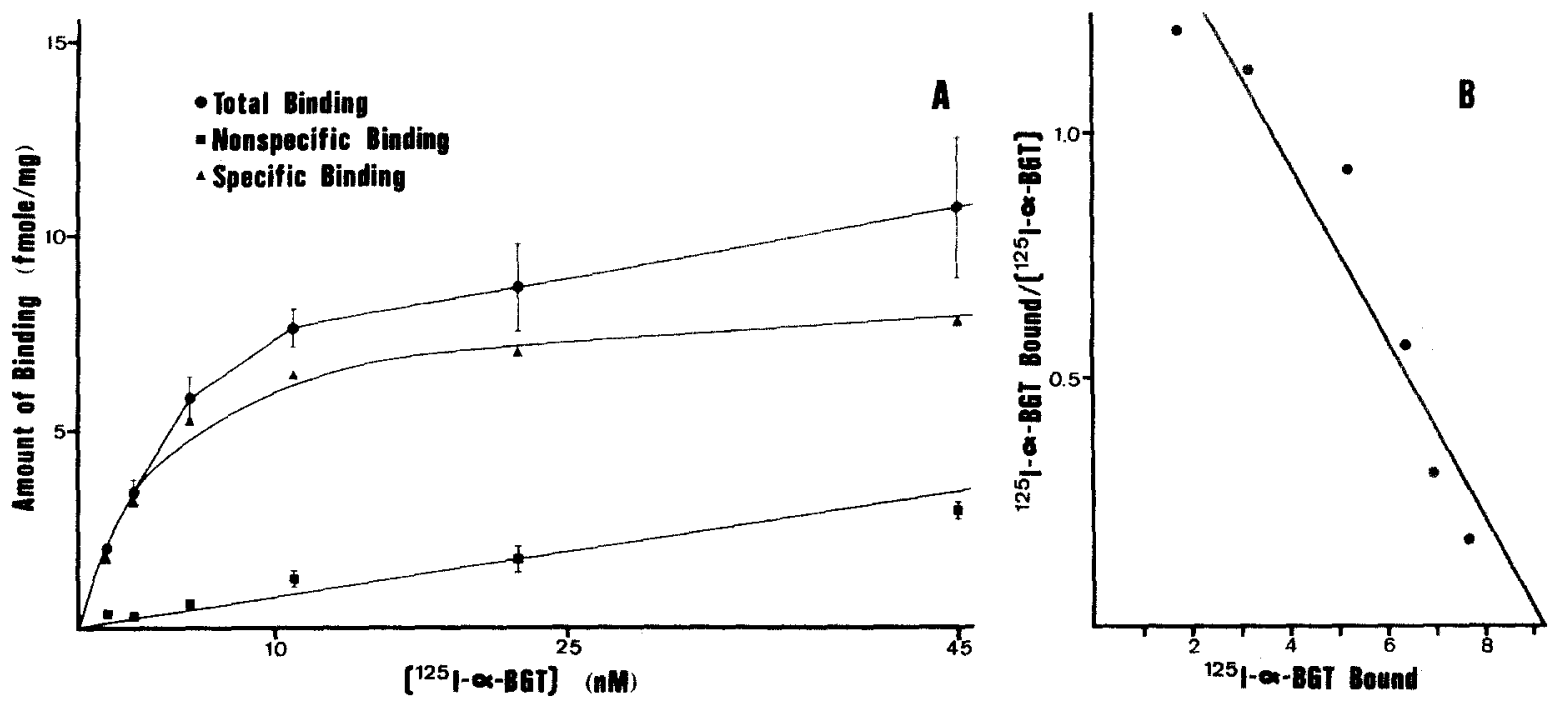

Fig. 2. A: concentration dependence of total, non-specific and specific [ $\left.{ }^{125} \mathrm{I}\right] \alpha-\mathrm{BGT}$ binding in cat carotid body. B: Scatchard analysis of specific binding data; $K_{d}=5.57 \mathrm{nM}, \mathrm{B}_{\max }=9.21 \mathrm{pmol} / \mathrm{g}$ of tissue. $r=0.951, P<0.01$.

Fig. 1. At a concentration of $11.25 \mathrm{nM}$, displaceable binding (i.e. binding in the presence of $10^{-3} \mathrm{M} \mathrm{ACh}$ ) plateaued at approximately $30 \mathrm{~min}$ and remained constant for incubation times up to $240 \mathrm{~min}$. At lower concentrations of ACh or D-TC $\left(10^{-4} \mathrm{M}\right)$, non-specific binding continued to increase with incubation times longer than $1 \mathrm{~h}$. This finding probably reflects a gradual increase in specific toxin binding, as has been shown to occur when the binding of a nearly irreversible ligand is blocked with drugs that bind reversibly ${ }^{10}$. At $10^{-3} \mathrm{M}$ ACh or D-TC, non-specific binding was always significantly less than total binding $(P<$ 0.005 ). In subsequent equilibrium studies, tissue samples were incubated for $30 \mathrm{~min}$, after the initial 20 min preincubation period with or without a blocking drug. At [125I] $\alpha$-BGT concentrations below $11.25 \mathrm{nM}$, however, equilibrium may not have been attained during the $30 \mathrm{~min}$ incubations, thus resulting in small overestimates of the $K_{d}$.

TABLE I

Inhibition of $/^{125} / \alpha-B G T$ binding

\begin{tabular}{llc}
$\begin{array}{l}\text { Drug } \\
\text { concentration }\end{array}$ & Amount bound (pmol/g) \pm S.E.M. \\
\hline Control & ACh & D-Tubocurarine \\
$10^{-6} \mathrm{M}$ & $7.64 \pm 0.52$ & $7.64 \pm 0.52$ \\
$10^{-5} \mathrm{M}$ & $7.79 \pm 1.26$ & $7.63 \pm 1.09$ \\
$10^{-4} \mathrm{M}$ & $5.50 \pm 0.88$ & $4.61 \pm 0.42$ \\
$10^{-3} \mathrm{M}$ & $2.13 \pm 0.49$ & $2.15 \pm 0.11$ \\
\end{tabular}

\section{Concentration dependence and inhibition of binding}

Equilibrium kinetic studies of [125I] $\alpha$-BGT binding in normal cat carotid bodies demonstrated a saturable component which was displaceable by $10^{-3} \mathrm{M}$ ACh (Fig. 2A) or D-TC. Specific binding plateaued at concentrations above $11.25 \mathrm{nM}$ toxin. The specific binding data in the figure are fit to a rectangular hyperbola by a 'best-fit' computer method. Non-specific binding appeared to be linear throughout the concentration range and never exceeded $27 \%$ of total binding.

The linear Scatchard analysis presented in Fig. 2B indicates a single population of binding sites with a $K_{d}$ of $5.57 \mathrm{nM}$ and a $B_{\max }$ of $9.21 \mathrm{pmol} / \mathrm{g}$ of tissue $(r=$ $0.951, P<0.01$ ). The Hill coefficient of the data is 0.876 , suggesting non-cooperative interaction between labeled toxin and the specific binding sites.

Inhibition studies showed that [125I] $\alpha$-BGT binding was progressively reduced by increasing concentrations of either D-TC or ACh (Table I). At concentrations between $10^{-6} \mathrm{M}$ and $10^{-3} \mathrm{M}$, the two drugs were similar in their ability to prevent toxin binding. In the presence of $11.25 \mathrm{nM}\left[{ }^{125 I}\right] \alpha-\mathrm{BGT}$, millimolar concentrations of $\mathrm{D}-\mathrm{TC}$ or $\mathrm{ACh}$ reduced the amount of bound radioactivity by $90 \%$.

Effects of carotid sinus nerve (CSN) denervation and sympathectomy on [125I] $\alpha-B G T$ binding

CSN-denervated and sympathectomized carotid 


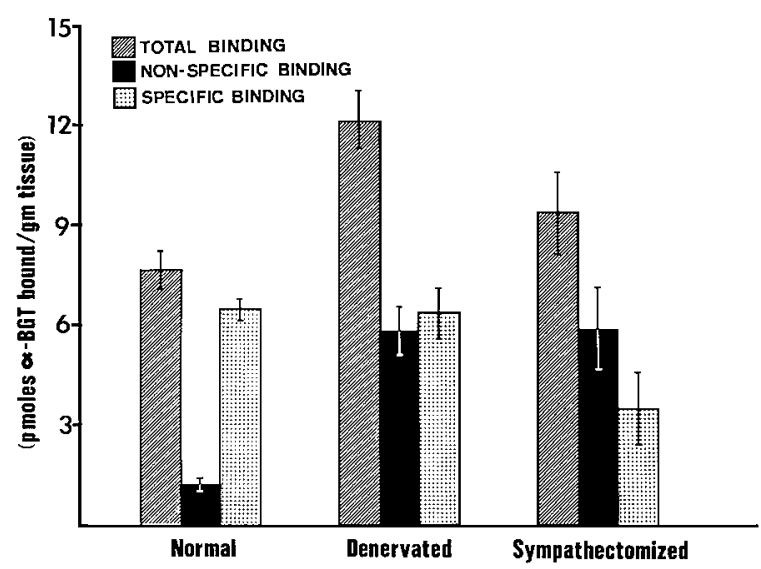

Fig. 3. [125I] $\alpha$-BGT binding in normal, CSN-denervated and sympathectomized (removal of superior cervical ganglion) cat carotid bodies. Note unaltered specific binding with increased non-specific binding 12-15 days following CSN-denervation. Sympathectomy reduced the specific binding by $46 \%$.

bodies were studied to further localize $\alpha$-BGT binding. It has been shown that degeneration of nerve terminals is complete within 12-15 days following either CSN transection or removal of the superior cervical ganglion ${ }^{33}$. Type I and type II cells in the cat carotid body appear largely unaffected by either procedure ${ }^{4.33}$. After CSN denervation, specific $\left[{ }^{125} \mathrm{I}\right] \alpha$ BGT binding in cat carotid bodies was unchanged (Fig. 3), suggesting that specific toxin binding sites are not present on CSN afferent fibers or their terminals. Non-specific binding, however, was increased in CSN-denervated carotid bodies. The reasons for this finding are not apparent, but may be related to the Schwann cell proliferation which has been shown to accompany nerve degeneration ${ }^{1}$.

The carotid body is innervated by sympathetic axons arising from the superior cervical ganglion ${ }^{16}$, and most of these fibers are post-ganglionic axons which terminate on vascular smooth muscle within the organ $^{41}$. Because presynaptic nicotinic receptors have been demonstrated on the terminals of adrenergic postganglionic neurons ${ }^{37.48}$, reductions in specific binding were anticipated in sympathectomized preparations. Indeed, our data showed that removal of the superior cervical ganglion resulted in a $46 \%$ decrease in specific binding, further suggesting that nicotinic receptors are likely associated with postganglionic sympathetic axons in the carotid body (Fig. 3). Non-specific binding in sympathectomized preparations was similar to that in CSN-denervated animals; i.e. significantly elevated above the levels of nonspecific binding found for normally innervated carotid bodies.

\section{Autoradiographic localization}

To localize specific [125I] $\alpha$-BGT binding sites in the carotid body, autoradiographic techniques were employed to determine whether significant toxin binding occurred within the lobules of type I and type II cells. As shown in Fig. 4, following incubation in $11.25 \mathrm{nM}\left[{ }^{125} \mathrm{I}\right] \alpha-\mathrm{BGT}$, the autoradiographic grain distribution in normal (A), CSN-denervated (B) and sympathectomized (C) tissues suggested that the iodinated toxin was concentrated amongst the parenchymal cell lobules. This technique did not permit visualization of small nerve endings $(<1.0 \mu \mathrm{m})$; nor is the autoradiographic resolution sufficient to differentiate binding on type I vs type II cells. The specific nature of this binding within the parenchymal cell lobules was demonstrated by the absence of silver grains over lobules following incubation in the presence of $10^{-3} \mathrm{M} \mathrm{ACh}$ (Fig. 4D).

\section{Physiological and pharmacological effects of $\alpha-B G T$}

The effects of $\alpha$-BGT on chemoreceptor nerve discharge and on endogenous catecholamine release were tested in carotid bodies preloaded with $\left[{ }^{3} \mathrm{H}\right]$ dopamine ([3 $\left.{ }^{3}\right]$ DA) synthesized from $\left[{ }^{3} \mathrm{H}\right]$ tyrosine (see Methods). Previous studies in our laboratory have established a proportional relationship between the level of hypoxia and the release of $\left[{ }^{3} \mathrm{H}\right] \mathrm{DA}$ from the carotid body in vitro ${ }^{21}$. In those studies, $\left[{ }^{3} \mathrm{H}\right] \mathrm{DA}$ release was also correlated with the chemoreceptor discharge recorded from the CSN. In the present experiments, both hypoxia (media equilibrated with $30 \%$ $\mathrm{O}_{2}$ ), as well as $10^{-5} \mathrm{M}$ nicotine were used as stimuli for assessing the effects of $\alpha$-BGT on transmitter release and nerve discharge.

The carotid bodies with their attached nerves were mounted in the in vitro recording chamber (see Methods), and superfused with $100 \% \quad \mathrm{O}_{2}$-equilibrated media for $30-40$ min prior to stimulation. $\left[{ }^{3} \mathrm{H}\right] \mathrm{DA}$ release and CSN discharge were then monitored during sequential $5 \mathrm{~min}$ pre-stimulus, stimulus and post-stimulus collection periods, which together comprised a single 'stimulus cycle'. Twenty minute rest periods ( $100 \% \mathrm{O}_{2}$ media) separated successive 'stimulus cycles'. After one hypoxic and one nicotine- 

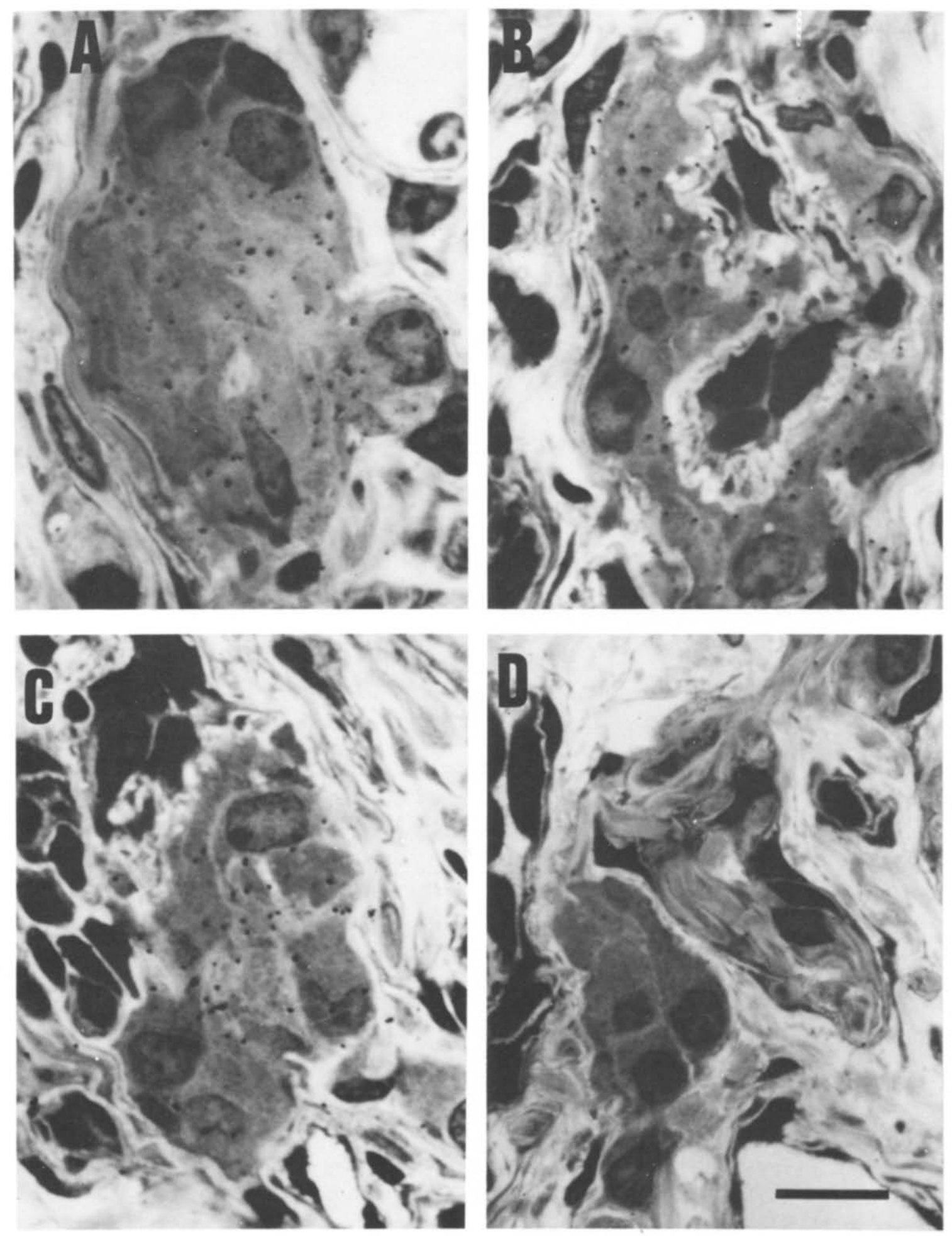

Fig. 4. Light microscope autoradiography of carotid bodies incubated for $30 \mathrm{~min}$ in $11.25 \mathrm{nM}[125 \mathrm{I}] \alpha$-BGT. Dark punctatc silver grains are localized over lobules of type I and type II cells in normal (A), CSN-denervated (B), and sympathectomized (C) Iissac. Silver grains are sparse following incubation in the presence of $10^{-3} \mathrm{M} \mathrm{ACh}$ (D). Scale $=10 \mu \mathrm{m}$. 


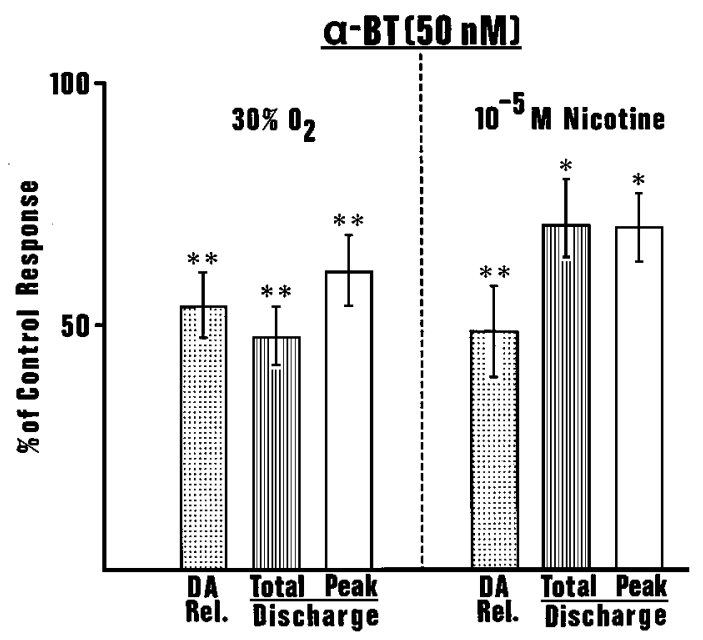

Fig. 5. Effects of $\alpha$-BGT on [ $\left.{ }^{3} \mathrm{H}\right] \mathrm{DA}$ release, and total and peak $\mathrm{CSN}$ discharge evoked by hypoxia $\left(30 \% \mathrm{O}_{2}\right.$ equilibrated media) or $10^{-5} \mathrm{M}$ nicotine. Data are expressed as percentages of control responses determined prior to the introduction of $50 \mathrm{nM} \alpha$-BGT. ${ }^{*}$ and ${ }^{* *}$ indicate $P<0.01$ and $P<0.005$ levels of significance, respectively.

stimulus cycle, the preparation was superfused for $1 \mathrm{~h}$ with $100 \% \mathrm{O}_{2}$ media containing $50 \mathrm{nM} \alpha$-BGT, and then re-exposed to each stimulus. The data in Fig. 5 compares [ $\left.{ }^{3} \mathrm{H}\right] \mathrm{DA}$ release and $\mathrm{CSN}$ discharge during control-stimulated vs toxin-stimulated collection periods (expressed as percent control response). Treatment with $\alpha$-BGT inhibited approximately $50 \%$ of the $\left[{ }^{3} \mathrm{H}\right] \mathrm{DA}$ release evoked by hypoxia or nicotine. Significant reductions were also observed in both total and peak CSN discharge. These changes persisted after $2 \mathrm{~h}$ of washing, and thus reflected the irreversible binding of $\alpha$-BGT. These reductions in the response to the stimuli could not have been ascribed to deterioration of the in vitro preparation since previous work in this laboratory ${ }^{21}$ has shown that stimulus repetitions over periods of more than $3 \mathrm{~h}$ result in slight increases, rather than decreases, in the response ratios.

\section{DISCUSSION}

Alpha-bungarotoxin binds nearly irreversibly to postsynaptic nicotinic receptors at mammalian neuromuscular junctions, where it causes prolonged blockage of synaptic transmission? ${ }^{7}$ High-affinity components of $\alpha$-BGT binding have also been described for mammalian central nervous system ${ }^{38,42,47}$, and sympathetic ganglia ${ }^{26}$. The toxin also blocks syn- aptic transmission in frog paravertebral ganglia ${ }^{39}$ and in the pigeon ciliary ganglion ${ }^{9}$. But in some tissues (e.g. the superior cervical ganglion), $\alpha$-BGT concentrations which normally saturate the high-affinity sites do not block the effects of endogenous $\mathrm{ACh}^{6,14,15,44}$. Thus, the significance of high affinity $\alpha$ BGT binding is equivocal in the absence of demonstrated physiological, biochemical or behavioral effects.

Our experiments indicate that [125I] $\alpha$-BGT binding in cat carotid body is not unlike its interaction with receptor sites in numerous other tissues. A $5.57 \mathrm{nM}$ $K_{d}$ is consistent with values established in brain $(1.7 \mathrm{nM} \text { and } 8.0 \mathrm{nM})^{38.47}$ autonomic ganglia $(\sim 2.0-3.0 \mathrm{nM})^{26}$ and mammalian skeletal muscle $(0.37 \mathrm{nM})^{5}$. Moreover, a high-affinity component of toxin binding in the carotid body is incrementally blocked in the presence of increasing concentrations of $\mathrm{ACh}$ and D-TC, suggesting that the toxin binds to nicotinic cholinergic sites in this organ. The kinetic data are consistent with the notion that cat carotid bodies contain high affinity $\alpha$-BGT binding sites similar to those found in skeletal muscle where $\alpha$-BGT selectively blocks postsynaptic nicotinic receptors ${ }^{7}$.

Our autoradiographic and biochemical studies show that normal and CSN-denervated carotid bodies bind comparable amounts of [125I] $\alpha$-BGT within the lobules of type I and type II cells. The simplest explanation for this finding is that afferent nerve terminals of the CSN do not possess specific nicotinic receptors. However, it must be noted that nerve terminals in the carotid body represent less than $5 \%$ of the total tissue volume ${ }^{52}$, and thus reductions in [125I] $\alpha$ BGT binding following denervation may be beyond our assay's limits of detection. An additional factor which might mitigate against detection of nerve terminal receptors is the ability of Schwann cells to bind $\left[{ }^{125} \mathrm{I}\right] \alpha-\mathrm{BGT}^{54}$. Since Schwann cells rapidly proliferate during nerve degeneration, and their increased numbers persist for many months following nerve transection ${ }^{1}$, any reductions in toxin binding which correspond to the loss of axons and nerve terminals may be masked by increases in Schwann cell toxin binding. On the other hand, we did observe significant reductions in toxin binding in sympathectomized preparations, where the loss of postganglionic nerve terminals probably represents an equally small volume of carotid body tissue, and where degeneration 
is also accompanied by Schwann cell proliferation. Thus, our data suggest that [125I] $\alpha$-BGT binding on afferent terminals may be absent. or quantitatively small, and that most of the cholinergic nicotinic receptors within the parenchymal cell lobules are localized to the type I and/or type II cells. Furthermore. the presence of such receptors in the cat carotid body is supported by the findings of Hayashida and Eyzaguirre ${ }^{30}$, who showed with intracellular recording that small doses of $\mathrm{ACh}$ increase the voltage noise and depolarize the type I cells.

Additional evidence for $\alpha$-BGT binding on type I cells has been provided by Chen and Yates'. Their studies with horseradish peroxidase conjugated $\alpha$ $B G T$ revealed binding to a select subpopulation of glomus cells in the rat carotid body. On the basis of dense-cored vesicle measurements, these authors concluded that the cells which bind the toxin correspond to the type B glomus cells identified earlier by MacDonald and Mitchell ${ }^{40}$. However, in other species, dense-cored vesicle studies have not demonstrated subgroups of glomus cells ${ }^{53}$. Information on this point is lacking in the cat, and from our data it is not possible to determine whether $\alpha$-BGT binds to a limited glomus cell population

The effects of $\alpha$-BGT on DA release and chemoreceptor discharge evoked by hypoxia or nicotine confirm the existence of specific nicotinic sites in the cat carotid body and, furthermore, suggest that $\alpha$-BGT blocks receptors which are functionally important for normal chemoreception. In the carotid body, DA is synthesized and released by type I cells ${ }^{20,21}$ and thus. the ability of $\alpha$-BGT to affect DA outflow. evoked

\section{REFERENCES}

1 Abercrombie, M. and Johnson, M. L., Quantitative histology of wallerian degeneration. I. Nuclear population in rabbit sciatic nerve, J. Anat., 80 (1946) 37-50.

2 Ballard, K. J. and Jones, J. V., The fine structural localization of cholinesterases in the carotid body of the cat, J. Physiol. (Lond.), 219 (1971) 747-753.

3 Ballard, K. J. and Jones, J. V., Demonstration of choline acetyltransferase activity in the carotid body of the cat, J. Physiol. (Lond.), 227 (1972) 87-94.

4 Biscoe, T. J. and Stehbens, W. E., Ultrastructure of the denervated carotid body, Quart. J. exp. Physiol., 52 (1967) 31-36.

5 Brockes, J. P. and Hall, Z. W., Acetylcholine receptors in normal and denervated rat diaphragm muscle. I. Purification and interaction with [ $\left.{ }^{125} \mathrm{I}\right] \alpha$-bungarotoxin, Biochemis- either by hypoxia or nicotine. suggests that cholner gic receptors located on type I cells in at carotid body modulate the release of atecholamnes. Con. sistent with this interpretation. Hellstrom et at, is found that depletion of rat carotid body $\mathrm{DA}$ by hypoxia was mimicked by methacholine and antagonized by atropine. Studies of transmitter outflow from the corpus striatum ${ }^{27}$ and hypothalamus ${ }^{50}$ have likewise revealed nicotinic and muscarinic receptors which. when activated, enhance the release of [ ${ }^{3} \mathrm{H} \mid \mathrm{DA}$. Hence, the carotid body may utilize a cholinergiclink mechanism to modulate DA release, as has been described for other catecholaminergic systems ${ }^{56}$.

In summary, a study of the localization and function of $\left[{ }^{125} I\right] \alpha-B G T$ binding in normal and denervated cat carotid bodies indicates that nicotinic cholinergic receptors are located on type I cells (and perhaps type II cells), as well as on post-ganglionic sympathetic nerve terminals. The binding sites on type I/type II cells are characteristically nicotinic and appear to modulate both the release of DA as well as the chemoreceptor discharge. The apparent absence of $[125 I] \alpha-B G T$ binding sites on the CSN suggests that carotid body chemosensation in the cat does not depend upon the activation of cholinergic receptors located on afferent terminals apposed to type I cells.

\section{ACKNOWLEDGEMENTS}

The authors wish to thank Ms. Vicki Skelton for skillfully preparing the manuscripts. Research supported by USPHS Grants NS 12636 and NS 07938.

try, 14 (1975) 2092-2099.

6 Carbonetto, S. T., Fambrough, D. M. and Muller, K. J., Non-equivalence of $\alpha$-bungarotoxin receptors and acetylcholine receptors in chick sympathetic neurons, Proc. nat. Acad. Sci, U.S.A., 75 (1978) 1016-1020.

7 Chang, C. C. and Lee, C. Y., Isolation of neurotoxins from the venom of Bungarus multicinctus and their modes of neuromuscular blocking action, Arch. Int. Pharmacodyn., 144 (1963) 241-257.

8 Chen, I. and Yates, R. D., Two types of glomus cell in the rat carotid body as revealed by $\alpha$-bungarotoxin binding, J. Neurocytol., 13 (1984) 281-302.

9 Chiappinelli, V. A., Cohen, J. B. and Zigmond, R. E., The effects of $\alpha$-and $\beta$-neurotoxins from the venoms of various snakes on transmission in autonomic ganglia, Brain Research, 211 (1981) 107-126.

10 Colquhoun, D. and Rang, H. P., Effects of inhibitors on the 
binding of iodinated $\alpha$-bungarotoxin to acetylcholine receptors in rat muscle, Molec. Pharmacol., 12 (1976) 519-535.

11 Crout, J. R., Catecholamines in urine. In D. Seligson (Ed.), Standard Methods of Clinical Chemistry, Academic Press, New York, 1961

12 Dinger, B., Gonzalez, C., Yoshizaki, K. and Fidone, S., Alpha-bungarotoxin binding in cat carotid body, Brain Research, 205 (1981) 187-193.

13 Docherty, R. J. and McQueen, D. S., The effects of acetylcholine and dopamine on carotid chemosensory activity in the rabbit, J. Physiol. (Lond.), 288 (1979) 411-423.

14 Duggan, A. W., Hall, J. G. and Lee, C. Y., Alpha-bungarotoxin, cobra neurotoxin and excitation of Renshaw cells by acetylcholine, Brain Research, 107 (1976) 166-170.

15 Dun, N. J. and Karczmar, A. G., Blockade of ACh potentials by $\alpha$-bungarotoxin in rat superior cervical ganglion cells, Brain Research, 196 (1980) 536-540.

16 Eyzaguirre, C. and Uchizono, K., Observation on the fibre content of nerves reaching the carotid body of the cat, J. Physiol. (Lond.), 159 (1961) 268-281.

17 Eyzaguirre, C. and Zapata, P., The release of acetylcholine from carotid body tissues. Further study on the effects of acetylcholine and cholinergic blocking agents on the chemosensory discharge, J. Physiol. (Lond.), 195 (1968) 589-607.

18 Eyzaguirre, C., Koyano, H. and Taylor, J. R., Presence of acetylcholine and transmitter release from carotid body chemoreceptors, J. Physiol. (Lond.), 178 (1965) 463-476.

19 Fidone, S. J. and Gonzalez, C., Catecholamine synthesis in rabbit carotid body in vitro, J. Physiol. (Lond.), 333 (1982) $69-79$.

20 Fidone, S. J. and Gonzalez, C., Peripheral chemoreceptors: initiation and control of discharge. In: Handbook of Physiology, in press.

21 Fidone, S. J., Gonzalez, C. and Yoshizaki, K., Effects of low oxygen on the release of dopamine from the rabbit carotid body in vitro. J. Physiol. (Lond.), 333 (1982) 93-110.

22 Fidone, S. J., Sato, A. and Eyzaguirre, C., Acetylcholine activation of carotid body chemoreceptor A fibers, Brain Research, 9 (1968) 374-376.

23 Fidone, S. J., Weintraub S. and Stavinoha, W. B., Acetylcholine content of normal and denervated cat carotid bodies measured by pyrolysis gas chromatography/mass fragmentometry, J. Neurochem., 26 (1976) 1047-1049.

24 Fidone, S. J., Weintraub, S., Stavinoha, W. B., Sterling, C. and Jones, L., Endogenous acetylcholine levels in the cat carotid body and the autoradiographic localization of a high affinity component of choline uptake. In H. Acker, S. Fidone, D. Pallot, C. Eyzaguirre, D. W. Lubbers and R. W. Torrance (Eds.), Chemoreception in the Carotid Body, Springer, Berlin, 1977, pp. 106-113.

25 Fuller, R. W. and Perry, K. W., Effects of lergotrile on 3,4dihydroxyphenylacetic acid (DOPAC) concentration and dopamine turnover in rat brain, J. neurol. Transm., 42 (1978) 23-35.

26 Fumagalli, L., De Renzis, G. and Miani, N., Acetylcholine receptors: number and distribution in intact and deafferented superior cervical ganglion of the rat, J. Neurochem., 27 (1976) 47-52.

27 Giorguieff, M. F., LeFloch, M. L., Westfall, T. C., Glowinski, J. and Besson, M. J., Nicotinic effect of acetylcholine on the release of newly synthesized ${ }^{3} \mathrm{H}$-dopamine in rat striatal slices and cat caudate nucleus, Brain Research, 106 (1976) 117-131.
28 Goldberg, A. M., Lentz, A. P. and Fitzgerald, R. S., Neurotransmitter mechanism in the carotid body: absence of $\mathrm{ACh}$ in the carotid sinus nerve, Brain Research, 140 (1978) 374-377.

29 Hanbauer, I. and Hellstrom, S., The regulation of dopamine and noradrenalin in the rat carotid body and its mod. ification by denervation and hypoxia, J. Physiol. (Lond.), 282 (1978) 21-34.

30 Hayashida, Y. and Eyzaguirre, C., Voltage noise of carotid body type I cells, Brain Research, 167 (1979) 189-194.

31 Hellstrom, S., Putative neurotransmitters in the carotid body. Mass fragmentographic studies, Adv. Biochem. Psychopharmacol., 16 (1977) 257-263.

32 Hellstrom, S., Hanbauer, I. and Costa, E., Selective decreases of dopamine content in rat carotid body during exposure to hypoxic conditions, Brain Research, 118 (1976) 352-355.

33 Hess, A. and Zapata, P., Innervation of the cat carotid body: normal and experimental studies, Fed. Proc., 31 (1972) 1365-1383.

34 Heymans, C., Bouckaert, J. J., Farber, S. and Hsu, F. J.. Influence reflexogene de l'acetylcholine sur les terminaisons nerveuses, chimiosensitives, du sinus carotidien, Arch. Int. Pharmacodyn. Ther., 54 (1936) 129-135.

35 Jones, J. V., Localization and quantitation of carotid body enzymes: their relevance to the cholinergic transmitter hypothesis. In M. J. Purves (Ed.), The Peripheral Arterial Chemoreceptors, Cambridge University Press, London, 1975 , pp. $143-162$.

36 Jones, J. V. and Ballard, K. J., Cholinesterases in the carotid body of the cat as seen with the electron microscope. Nature (Lond.), 233 (1971) 146-148.

37 Lee, W. C. and Shideman, F. E., Mechanism of the positive inotropic response to certain ganglionic stimulants, J. Pharmacol. exp. Ther., 126 (1959) 239-249.

38 Lukasiewicz, R. J. and Bennett, E. L., $\alpha$-Bungarotoxin binding properties of a central nervous system nicotinic acetylcholine receptor, Biochim. biophysica Acta, 544 (1978) 294-308.

39 Marshall, L. M., Synaptic localization of $\alpha$-bungarotoxin binding which blocks nicotinic transmission at frog sympathetic neurons, Proc. nat. Acad. Sci. U.S.A., 78 (1981) 1948-1952.

40 McDonald, D. M. and Mitchell, R. A.. The innervation of glomus cells, ganglion cells and blood vessels in the rat carotid body: quantitative ultrastructural analysis, J. Neurocytol., 4 (1975) 177-230.

41 McDonald, D. M. and Mitchell, R. A., The neural pathway involved in 'efferent inhibition' of chemoreceptors in the cat carotid body, J. comp. Neurol., 201 (1981) 457-476.

42 McQuarrie, C., Salvaterra, P. M. and Mahler, H. R., Studies on nicotinic acetylcholine receptors in mammalian brain, J. biol. Chem., 253 (1978) 2743-2747.

43 McQueen, D. S., A quantitative study of the effects of cholinergic drugs on carotid chemoreceptors in the cat, J. Physiol. (Lond.), 273 (1977) 515-532.

44 Miledi, R. and Szczepaniak, A. C., Effects of Dendroaspis neurotoxins on synaptic transmission in the spinal cord of the frog, Proc. roy. Soc. B, 190 (1975) 267-274.

45 Moe, G. K., Capo, L. R. and Peralta, B., Action of tetraethylammonium on chemoreceptor and stretch receptor mechanisms, Amer. J. Physiol., 153 (1948) 601-605.

46 Monti-Bloch, L. and Eyzaguirre, C., A comparative physiological and pharmacological study of cat and rabbit carotid 
body chemoreceptors, Brain Research, 193 (1980) 449-470.

47 Moore, W. M. and Brady, R. N., Studies of nicotinic acetylcholine receptor protein from rat brain, Biochim. biophysica Acta, 444 (1976) 252-260.

48 Nedergaard, O. A. and Schrold, J., The mechanism of action of nicotine on vascular adrenergic neuroeffector transmission, Europ. J. Pharmacol., 42 (1977) 315-330.

49 Nishi, K. and Eyzaguirre, C., The action of some cholinergic blockers on carotid body chemoreceptors in vivo, Brain Research, 33 (1971) 37-56.

50 Perkins, N. A. and Westfall, T. C., Influence of cholinergic agents on dopamine release from medial basal hypothalamus, Neurosci. Lett., 11 (1979) 283-287.

51 Sampson, S. R., Effects of mecamylamine on responses of carotid body chemoreceptors in vivo to physiological and pharmacological stimuli, J. Physiol. (Lond.), 212 (1971) 655-666.

52 Seidl, E., Schafer, D., Zierold, K., Acker, H. and Lubbers,
D. W., Light-microscopic and electron-microscopic studies on the morphology of cat carotid body. In H. Acker. S. Fidone, D. Pallot, C. Eyzaguirre, D. W. Lubbers and R. W. Torrance (Eds.), Chemoreception in the Carotid Body, Springer, Berlin, 1977, pp. 1-8.

53 Verna, A., Dense-cored vesicles and cell types in the rabbit carotid body. In H. Acker, S. Fidone, D. Pallot, C. Eyzaguirre, D. W. Lubbers and R. W. Torrance (Eds.), Chemo. reception in the Carotid Body. Springer, Berlin. 1977, pp. $216-220$

54 Villegas, J., Effects of cholinergic compounds on the axon-Schwann cell relationship in the squid nerve fiber, Fed. Proc., 34 (1975) 1370-1373

55 Weil-Malherbe, H., Determination of catecholamines. In D. Glick (Ed.), Analysis of Biogenic Amines and Their Related Enzymes, Interscience, New York, 1971

56 Westfall, T. C., Local regulation of adrenergic neurotransmission, Physiol. Rev., 57 (1977) 659-728. 